\title{
Tracing Southern Cosmopolitanisms: The Intersecting Networks of Islam, Trade Unions, Gender \& Communism, 1945-1965
}

\author{
Heather Goodall \\ University of Technology, Sydney
}

\begin{abstract}
This paper investigates the continuing relationships between Australian, Indonesian and Indian unionists and activists in the aftermath of an intense political struggle in Australia from 1945 to 1949 in support of Indonesian independence. These groups had been brought together initially by intersections between the networks established through colonialism, like trade unions, communism and feminism, with those having much longer histories, like Islam. The men and women in this Australian setting expressed their vision in 1945 for a future of universal and transnational networks across the Indian Ocean which would continue the alliances they had found so fruitful. Their experiences as well as their hopes can be called cosmopolitanism and were 'southern' in the sense that they drew on subaltern, non-western and/or anti-colonial networks in all three countries. Although these hopes for new futures of universal alliances and collaborations were held passionately in the 1940s, all seem to have died by 1970, diverted by newly independent national trajectories and defeated by the Cold War. Yet many of the relationships persisted far longer than might be expected and their unravelling was not inevitable. This paper will trace the course of a few of the relationships which began in the heat of the campaigns in Australia, 1943 to 1945, in order to identify the continuing common ground as well as the rising tensions which challenged them.
\end{abstract}

At the end of World War 2, there were high hopes across the Indian Ocean for a new world in which the relationships between working people would mean more than the borders which separated them. This paper will explore the fate of such hopes in the decades after 1945, by following the uneven relationships among Australians, Indonesians and Indians in the aftermath of an intense political struggle in Australia from 1945 to 1949 in support of Indonesian independence.

The men and women in this Australian setting expressed their vision in 1945 for a future of universal and transnational networks across the Indian Ocean which would continue the alliances they had found so fruitful. Today their experiences as well as their hopes might be called cosmopolitanism - they expected that the person-to-person friendships they were forming could be sustained and be able to negotiate the differences between them to achieve 
common aims. ${ }^{1}$ This hope was expressed by some of the departing Indonesians in December 1945 to Dasrath Singh, the secretary of the Indian Seamen’s Union in Australia:

"We hope for an everlasting friendship and cooperation between the Indonesian and Indian people in general, and the Indonesian and Indian workers in particular, both struggling for national independence, freedom and humanity” (Fadilla and Soemadi 1945).

Yet they drew on a wider range of ideas and traditions than the classical 'cosmopolitan' of European politics at the time. These were 'southern cosmopolitanisms' in that they were relationships between colonised peoples and across racial and imperial lines - in the gaps between empire authorities and outside their control. Australia had been a settler colony and had achieved nominal independence, yet it continued to be dominated by metropolitan political and economic interests, leading to widespread, vigorous republican and anti-British sentiments. India and Indonesia shared their colonial conditions: both were administered (or indirectly ruled) colonies with minority colonising populations but these colonies spoke different vernaculars and were governed by different empires. The relationships which occurred between the three in Australia in 1945 were between marginalised working people, all of whom were unhappy with their different types of colonial roles.

The networks had been nurtured in the long nineteenth century when relative peace allowed mobile colonised peoples to explore the networks the European empires had built. Some of these visions of a new future arose from networks of cultural expression, like those fostered by Rabindranath Tagore on his travels from India to Iran and Yugoslavia in the west to Indonesia and Japan to the east (Bose 2010; Frost forthcoming). Other visions were drawn from religious faiths, particularly from Islam, a universalist faith in the Indian Ocean long before colonialism (Frost 2004, 2010; Reetz 2006; Germain 2007). While there are many differences across geographies and between doctrinal expressions within Islam, all shared an understanding of an ummah or collective of believers (Ummah Wahida or 'one community' in the Qur'an) that is the whole Islamic world. Still other visions were drawn from the

\footnotetext{
${ }^{1}$ This is roughly the definition in use in current critical literature: a focus on individual relationships which enable interactions across group, class or cultural lines, across or beyond 'national' border, see for example: essays by both Bruce Robbins or Pheng Cheah in their 1998 co-edited volume Cosmopolitics: Thinking and Feeling Beyond the Nation, Special Issue of Cultural Politics, Vol 14, Uni of Minnesota Press, Minneapolis; Carol Breckenridge, Sheldon Pollock, Homi Baba and Dipesh Chakrabarty (eds) 2002: Cosmopolitanism, Duke University Press, Durham and London; Gerard Delanty, 2009: The Cosmopolitan Imagination: The Renewal of Critical Social Theory, Cambridge University Press, Cambridge, UK; Chris Rumford 2008: Cosmopolitan Spaces: Europe, Globalisation, Theory, Routledge, NY and London; and Gill Valentine 2008: 'Living with Difference: Reflections on geographies of encounter’ in Progress in Human Geography 32(3) pp323-337.
} 
common experiences of working people, whether they were among the indentured labourers sent across the empires to work on colonial plantations, or among those organising themselves into trades unions around the port cities and on the ships on the newly global imperial trade routes (Broeze 1981, 1998; Manjapra 2010; Martínez 2001). Yet again, the networks which arose through contacts between travelling men and the women in the places they visited, either as tourists or workers, have not been well examined, despite having existed throughout this long period of peace. Some were those of sex work and ranged from astute cultural calculations to brutal exploitation. Others were enduring and affectionate relationships, occasionally resulting in marriages and the resettlement of one or other partner. Still others, and this is very clear in the 1945 situation in Australia, were social and political relationships, born out of the broader expectations which were the result of rapid change and challenge in the mid-twentieth century.

Such networks did not arise from the conditions generating 'cosmopolitanism' inside Europe. Bose for example has stressed the Asian roots of what he calls 'universalism' while Frost has identified Islam as a structure entirely outside European control within which such networks were formed. Yet what is notable about each of these networks is that they drew not only from pre-colonial and non-western technologies and ideas but at the same time from those initiated from Europe. Although he was only marginally interested in Europe, Tagore travelled on the vessels of European empires in order to explore the Asian cultural worlds he was hoping to bring together. Islam had gained from the new transport networks established by colonisation, both through the cultural influences of the expanding numbers of steam ship crews who were often Muslims and through the ships themselves, which offered new and cheaper routes to the Haj for far flung Muslim communities established by the earlier sailing traders. The networks of mobile working people, whether among indentured labourers or the seafaring lascars (largely from India) and seedies (Arabic-speakers from Aden) (Ewald 2000) had all arisen from the economies and technologies of empire, even though they built some of their relationships on the older ties of language and local home cultures as well as new industrial conditions and strategies. The relationships between men and women across cultures arising in port cities through sea transport, although long established with sail, had been greatly accelerated in the age of expanding Imperial trade and proliferating steam ship routes (Falkiner 2008). 
Finally, there were organizational structures like international conferences and regular newsletters which had been initiated in the political movements of the west, like Marxism and feminism, but which drew in and linked non-western peoples. The ideas of these political movements had been challenged and reshaped as they circulated in colonised settings where non-western 'universalisms' existed alongside assertive new local cultural movements. The international organisations of the 1920s deemed 'communist' for example, like the League Against Imperialism, were often seen by western commentators as being entirely under western - in this instance, Soviet - domination. But they can be seen to have operated like the material structures of the shipping lanes, in that they formed structures - although intellectual structures rather than material ones - which acted as conduits for flows of debate and contestation in many directions, not just from Europe to the colonised world.

The hopes for new futures of universal alliances and collaborations were held passionately in the 1940s, yet all seem to have died by 1970. The bitter struggles to force out colonisers led to national identities which were inward-looking, as newly independent peoples tried to define and authenticate themselves, as well as to justify their new borders. Hampering transnationalism as well was the fact that borders continued to be problematic after Independence. In the Dutch East Indies, for example, there had been deep ambivalence from the earliest years of the twentieth century in a number of communities, including among the Sumatrans and the Javanese, about whether their emerging 'nation' should embrace all of the islands in the archipelago which had been controlled by the Dutch, despite religious and ethnic differences, and indeed whether it should include the Malay population of British Malaya (Zurbuchen 2005; Kumar 1979; Anderson 1979; Reid 1979).

This ambivalence and debate continued to be unresolved - at least in part - because even after 1949, the Dutch retained control over Irian Jaya, ${ }^{2}$ a place which had long held emotional significance for nationalists because it was where the Dutch had imprisoned many Indonesian political prisoners, including Haji Misbach, the 'red haji of Solo', a high profile communist member of Serakat Islam, in 1924 and over 1300 Communist Party activists and others in 1927 (McVey 1965; Shiraishi 1990; Ricklefs 2001; Federspiel 2006). Although its population was Melanesian, Irian Jaya had no greater differences in ethnicity and religion than did other islands now included in the new independent Republic. Hostilities between the Indonesians

\footnotetext{
${ }^{2}$ Known by various names, including Dutch New Guinea and West Papua.
} 
and the Dutch over Irian Jaya had flared into international consciousness by the early 1950s as we shall see. Inside Indonesia there was intense popular anger that even after such a bloody independence battle in the 1940s the Dutch continued to be intransigent in holding onto their last foothold of colonialism. This ensured that, despite ambivalence inside Indonesia over the challenges of extending the borders, the Indonesian government demanded that the UN declare incorporation into the Indonesian nation and eventually invaded Irian Jaya in 1961. Border insecurity and nationalist assertiveness was not limited to Indonesia. In India, bitterness over the border with Pakistan was paralleled by rising conflict with China over the borderline on the north east. India stationed armed troops there and increasingly severe border clashes marked the later 1950s until open warfare broke out in 1962. At the same time, Cold War politics on all sides had forced everyone - still colonised or not - to recompose themselves in regional and political 'camps' or 'blocs' as the hostile polarisations lined up through the 1950s. All these were ongoing processes, generating occasional peaks of crisis but often simmering, yet still shaping both internal and international political relationships.

There were also, however, some obvious landmarks of sudden change which are usually used as explanations. There was the end of the world war itself in May 1945, then Indian Independence in 1947 and the tragedy of Partition, which split the memberships of at least some unions like those for the seafarers who had sailed as Indians but who lived across all sides of the borders of India, and West and East Pakistan. The Indonesian battle against the Dutch went on for far longer - and was accompanied by much more internal bloodshed among the nationalists - than had been expected in August 1945. Independence was finally achieved only in December 1949, after years of isolation behind a Dutch blockade. In Australia, there had been rising conflict between left and right inside the Labour movement, with pressure on left members and organisations to declare their distance from the Australian Communist Party (CPA) and withdraw from all Soviet-aligned international organisations. Labor lost the election in December 1949 to Robert Menzies, who led a deeply conservative government to power for 23 years, entrenching an alignment with the USA in the Cold War hostilities.

Were these abrupt events - dramatic as each was - enough to sever the alliances formed during the campaign against the Dutch? Many of the networks in existence in 1945 persisted in fact into the 1950s and even the 1960s, beyond these major landmarks. Some indeed, like 
the connections between women, seemed to have gone beyond the fragile links of the 1940s to expand in the early 1960s. They all continued to be marked by warm friendships and sustained communication. So if it was not those early disruptive events, what was the cause of the eventual loss of these networks? Their persistence begs for closer study, to understand not only their victories but also their eventual defeats even after so much effort had gone into keeping them alive.

This paper will briefly trace three of these intersections between non-western and western networks. The first is the relationship between Islam and communism. The second is around trades union organisation and strategies in established and newly independent nations. The third is around gender and sexual relationships across racial lines, the area far less often investigated than the other two in the recent scholarship on cosmopolitanism (cf Stivens 2008), yet arguably one which was sustained the longest. There are publications around some of these themes, but most are focussed within national borders, seldom drawing international comparisons. Each of these intersections was visible in 1945 in the Australian campaign to support Indonesian independence and they can be seen to exist, with varying degrees of tension, in events up to the 1960s.

The campaign in Australia to support the Indonesian declaration of an Independent Republic in August 1945 was carried out through a boycott of Dutch shipping (Lockwood 1982; Fitzpatrick and Cahill 1981; Cottle 2003; Beasley 1996; Goodall 2008; Cottle and Keys 2005) initiated by Indonesian seamen and activists caught in or brought to Australia when the Japanese invaded Dutch East Indies in 1942. It was then taken up by Australian maritime unions and others including the Indian Seamen's Union in Australia (ISUiA). These unions all refused to load, service or crew any Dutch shipping or other shipping carrying arms or supplies to the Dutch. The boycott was spectacularly effective, holding up around 500 ships in Australian waters for nine months and completely stopping the Dutch and British in that period from re-establishing colonial power over what had been Netherlands East Indies (Lockwood 1982). The Dutch ramped up their physical attack on the Indonesian Republican areas and then imposed a naval blockade around them, but the Independence movement continued to call for support from governments they believed to be sympathetic in Australia, Vietnam, India and the Philippines (Raliby quoted in Anderson 1976, p.179). Although less uniformly observed by 1947, the boycott continued to act as a significant obstruction to 
Dutch supply lines and as a constant reminder to the Australian public of the battle going on to their north.

The campaign brought together not only Australians and the Indonesian seafarers and political activists but involved all the seamen, from many nationalities, who were temporary residents in Australia, because they were the crews on the foreign vessels, including the Dutch and British, which were being used to reinforce the Dutch as they tried to retake the NEI (Lockwood 1982, p.170; Cottle 2003). These seafarers included Chinese, Vietnamese and Papuan sailors, but most notable were the Indians who were in the greatest numbers, crewing all of the British and many of the Dutch ships. ${ }^{3}$ Often stereotyped by later Australian authors (Fitzpatrick and Cahill 1981) as subservient workers and unreliable allies, the Indians played a key role in the strike. They were not only highly unionised and militant in India itself (Broeze 1981) but formed a union for themselves while in Australian waters, the ISUiA which has left many documents to record the Indian views and statements about the strike. ${ }^{4}$ This article, addressing the years 1945 to 1965, will focus on the ongoing relationships between Indonesians and Australians, as the Indians appear to have taken a less active role on the international stage in those years. ${ }^{5}$ Yet the Indian experience forms an essential comparative backdrop in considering the interactions between Indonesians and Australians, particularly in relation to Islam, which otherwise might be interpreted very differently.

\section{Intersection 1: Islam and Communism}

The rapidity with which ideas around socialism from the 1880s and then communism after the Russian Revolution were circulating globally owed much to the travels of colonised peoples for trade, education or business into Europe as well as into the rest of the colonised world. Most of the high profile advocates of anti-colonial and nationalist movements from the colonised world had spent some time in their respective metropolitan countries or in other European centres. Often this was in events or conferences which were associated with the

\footnotetext{
${ }^{3}$ The majority of iconic ships immobilized in Sydney - including those named in the film Indonesia Calling had been crewed by Indians. See list in Tribune, Tues 23 October, 1945, p 1, 'Indians Prevent Dutch Getaway', and Friday 26 October, p 3, 'Indians Defy Dutch, Enter Lido.', Tues 30 October, 1945, 'Indians Establish Complete Dutch Ship Boycott'.

${ }^{4}$ At the Noel Butlin Archive of Business and Labour, Menzies Library, Australian National University. Rupert Lockwood recorded many of the Indian strike details but focussed his story on the Indonesians. For an account focussed on the Indian records, see Heather Goodall 2008: 'Port Politics: Indian Seamen, Australian unionists and Indonesian Independence, 1945-1947’, Labour History, No. 94, May 2008, pp 43-68.

${ }^{5}$ The next stage of my research will be the exploration of documents in Indian archives to identify what obstacles there may have been to international participation 1947 to 1965, as is suggested by the IndonesiaAustralia comparison.
} 
emerging ideologies of European countries like Soviet Russia, but it is an illusion to see these individuals or their long established movements as falling under any immediate Soviet discipline. Kris Manjapra, investigating South Asian and Indian Ocean communism, has argued that the Soviets sought little control until after Stalin's rise in 1928 over the far flung and emerging communist parties in the colonies - and in fact would have had had great difficulty imposing any single 'line' even then on the tumultuous ferment of ideas which was being debated and circulated between the anti-colonial and nationalist movements both in European cities and in their homelands (Manjapra 2010a, pp.167-170; Manjapra 2010b).

The iconic conferences held under the auspices of the international communist and socialist movements in Europe in the 1920s saw a great diversity in attendance as well as debate and contestation about content. Both Jawaharlal Nehru and Mohammed Hatta attended the League against Imperialism conferences in 1927 and 1929, along with European pacifists and the anti-colonial left. Neither Nehru nor Hatta ever toed any European directive, let alone a Soviet one, and some like Hatta went to great lengths in the 1940s and beyond to prove their implacable resistance to communism. Kyaw Zaw Win (2011) along with Manjapra and others have pointed to the Pan-Islamic conference at Mecca, in 1926 as being just as - if not more influential in the region. Win points to the Pan-Asiatic Conference in Nagasaki, also 1926 and the networks of socialists throughout the region, who became visible in the early 1950s in, for example, the Rangoon Asian Socialist Conference in 1953, as being different but similarly active and explicitly non-western and anti-colonial networks, which exerted strong influences over nationalist activists generally (Win 2011; Manjapra 2010).

One issue over which there was particular and continuing tension between communists in the Indian Ocean and those in the Soviet Union was Islam. The career and statements of Tan Malaka demonstrate the intensity of this issue and the lack of control over non-western communists which the Comintern could command in the early 1920s. Malaka was not by any means alone in Indonesia - there was widespread affiliation to both Islam and Communism among members of the organisation Sarekat Islam (SI), founded around 1908 with an economic rather than primarily a religious function. Until the mid 1920s, SI was made up of a wide range of members, many of whom were not only Islamic but were either in the Indonesian Communist Party (PKI) like Haji Mesbich, the 'Red Haji of Solo', from Central Java, or were strongly sympathetic to socialist and communist policies and strategies (McVey 1965, pp.172-3; Shiraishi 1990; Ricklefs 2001; Federspiel 2006). Tan Malaka (1894-1949) 
was a Sumatran who was a committed nationalist and communist, studying in the

Netherlands where he was inspired by the Russian Revolution. Returning to Indonesia in 1919, he became Chairman of Indonesian Communist Party (PKI) but was exiled by the Dutch in 1922, again arriving in the Netherlands. Soon after, he ran as a Communist candidate for the Dutch parliament, then, on his defeat, moved to Moscow to become the Comintern's officer for SE Asia. ${ }^{6}$

Lenin, in his influential Theses adopted at the Second Comintern Congress in 1920, had emphasised the need to 'struggle against Pan-Islamism.' This statement had been republished by the PKI in Indonesia, alienating many in Sarekat Islam. Tan Malaka addressed the Fourth Comintern Congress in 1922 on 'Communism and Pan-Islamism'. He argued that the PKI had worked closely with Sarekat Islam - which he described as 'the Islamic League .... a very large organisation with many very poor peasants', until 1921, when minor differences between them were exploited by the government to briefly separate them. Cooperation had been restored within the year and their relationship was so close, he explained accurately, that Sarekat Islam had campaigned on the same electoral platform as the PKI. He went on to say:

\begin{abstract}
'Today, Pan-Islamism signifies the national liberation struggle.... Pan-Islamism now means the brotherhood of all Muslim peoples, and the liberation struggle not only of the Arab but also for the Indian, the Javanese and all the oppressed Muslim peoples. This brotherhood means the practical liberation struggle not only against Dutch but also against English, French and Italian capitalism....the liberation struggle against the different imperialist powers of the world.... Just as we want to support the national struggle, we also want to support the liberation struggle of the very combative, very active 250 million Muslims living under the imperialist powers (Malaka 1922).’
\end{abstract}

This position was rejected in Moscow just as it was by many western Communists, but it had a powerful resonance in India, particularly among the unionised seafarers from Bengal who formed a major proportion of those in Sydney in 1945. Historian Suchetana Chattopadhyay has traced the emergence of Bengal's first communists in the early 1920s from the region's Muslim intelligentsia (Chattopadhyay 2011, pp. 1-6). The Communist Party of India continued to have a significant proportion of Muslims, and it was influential during the 1920s and 1930s in the seamen's unions operating in the two big ports of the region, Bombay and Calcutta (Chattopadhyay 2011, pp. 178-9, 218). These Indian unions were, in turn, strongly

\footnotetext{
${ }^{6}$ Tan Malaka's own voluminous writings were gathered and translated by Helen Jarvis and published in English in 1991 as From Jail to Jail. Athens, Ohio: Ohio University Center for International Studies Southeast Asia series number 83. A number of authors have discussed Tan Malaka, including George McTurnan Kahin, 1952: Nationalism and revolution in Indonesia. Ithaca, NY: Cornell University Press; Ruth McVey, 1965: The rise of Indonesian communism. Ithaca, NY: Cornell University Press; Helen Jarvis 1987: 'Tan Malaka: revolutionary or renegade?' Bulletin of Concerned Asian Scholars 19(1): 41-55; Abidin Kusno 2003: 'From city to city: Tan Malaka, Shanghai, and the politics of geographical imagining'. Singapore Journal of Tropical Geography 24(3): 327-339.
} 
represented in the Indian Seamen's Union in Australia, whose members continued to practice their Islamic faith throughout the strike and boycott of Dutch shipping. The ISUiA records indicate that at a minimum $70 \%$ of the seamen in Australia were Muslims and the proportion may have been higher (Goodall 2010). A photograph published in the Australian Communist newspaper, The Tribune in November 1945 showed Dasrath Singh, the Sikh secretary and Abdul Rehman, the Islamic President of the ISUiA in Sydney with the visiting Dr Muhammad Hassan, a barrister who came from India to be the Imam during the 1945 Eid-ulFitr ceremonies hosted by the Indian Seamen's Union in Australia during the strike (Tribune 23 November 1945, p.8).

For the Australians most directly involved in the ISUiA, like Clarrie Campbell, the seafarers' commitment to Islam was obvious and they took it seriously. Campbell assisted in compiling a list of the names and addresses of Sydney's Muslim community in 1946 to be invited to attend the Eid celebrations which the ISUiA hosted and to compose the respectful letters of invitation in English which the Union issued. In wider circles, however, among the largely atheist left of the Union movement and the Communist and Socialist parties, the Indian seamen's diverse faiths were noted but assumed to be unimportant. Australians interviewed for this project confirmed they were aware of religious differences largely because there were problems whenever the Australians tried to organise food purchases or cooking. They learnt quickly that things went far more smoothly when the seafarers themselves managed the strikers' kitchen for all traditional food requirements - Christian, Muslim and Hindu. Australian observers of the seafarers' tactful management of dietary differences were delighted at what they took to be a growing 'ecumenism' among the striking seamen which would involve, as reductivist versions of Marx advocated, the eventual 'withering away' of organised religion. At most, these Australians saw such religious differences as quaint and outmoded customs. ${ }^{7}$

For many of the Indians and the Indonesians, however, the role of Islam in fostering international unity among Muslims was extremely important. The Indians pointed out in November 1945:

"The Indonesians are 98\% Mohammedan and the Indian seamen in Sydney are 98\% Mohammedans,” said one Indian spokesman. "Thus the shipping companies are trying to force us to take part in a war on our brother Mohammedans. This is against our conscience, as well as being against the law” (Tribune, 30 October 1945).

A group of Indian crewman after refusing to sail a Dutch ship said:

"We made our attitude quite clear. We were simply not going to Java and help suppress our brothers, and that as all there was to it.” (Tribune, 2 November 1945).

The celebration of Eid-ul-Fitr in 1945 was - no doubt like others - intensely political. A Tribune photograph was captioned:
"Indian nationals and Indonesians gathered outside the Sydney Town Hall after celebrating the Mohammedan New Year Festival led by Indian barrister and Muslim priest, Muhammad Hasan. Crowd cheered when Mr Hasan advised that success in the

\footnotetext{
${ }^{7}$ Phyllis Johnson (born 1917), interviewed Heather Goodall, Padstow, NSW, 10 May 2007.
} 
struggle for independence depended on unity among those seeking fulfilment of promises made in the Atlantic Charter.” (Tribune 27 November 1945, p.7)

Differences in Empires, languages and shipping lines had kept the Indians and Indonesians separated in the past, although the Indian seafarers commented bitterly that they believed this was due to the shipping companies seeking to 'divide and rule'. One Indian organizer put it this way when he spoke formally to the Indonesians at a shared function:

\begin{abstract}
We Indians are indeed grateful that you accepted our invitation to join us in this picnic today. We feel that in doing so, we have welded a chain of fraternal friendship which no force can break ... In the past there have been small conflicts between Indian and Indonesian seamen ... We know now that in spite of the urgency of winning the war, certain shipping companies in their greed for profits, and even at the risk of losing the war, were prepared to use the people of one country against another ... The unity of our people, the people of two important countries . . . ensures our ultimate emancipation. ${ }^{8}$
\end{abstract}

At this event in Sydney, both groups pledged that in the future they would put aside such colonisers' divisions and instead concentrate on the bonds of religion and class politics which rightly drew them together.

In India and Indonesia, however, the relationship between the Communist Parties and Muslims had taken very different paths, even before Partition in India in 1947. In Indonesia, the divisions which Tan Malaka had spoken of between Muslims and Communists in the 1920s had widened, in part because the Comintern had failed to adopt Tan Malaka's argument about supporting the liberation struggles of 250 million Muslims under colonial control. Tensions repeatedly surfaced during the course of the Revolution in Indonesia, exacerbated for example in the aftermath of complex events like the Madiun Uprising in 1948 (McGregor 2009) and were eventually to widen in some areas into a bitter and apparently irreparable gap, as will be discussed later in this paper. ${ }^{9}$ In India, however, the strong affiliations between Communism and Islam continued, ensuring that Muslims continued to play active roles as Marxists and in Marxist parties and governments throughout the early decades of Independence and into the present.

\footnotetext{
8 'Indians Reply to Indonesians' typescript, nd [possibly September 1945 but also may have been pre-August as it refers to the war as if it had not yet ended], ISUiA Archive E177/5. Noel Butlin Archive of Business and Labour, ANU.

${ }^{9}$ There are a number of reflections on the bitter division which had come into existence by 1965 in Indonesia and its persistence to this day. See Greg Fealy and Katharine McGregor, 2010: 'Nahdlatul Ulama and the Killings of 1965-66: Religion, Politics and Remembrance’ in Indonesia, 89, April 2010, pp 37-60.
} 
In Australia, however, most Communists had ignored the importance of Islam in fostering communication between left wing Indian and Indonesian seafarers. They had expected that all religions would be opposed to communism, and so they continued to assume that communism and Islam were by definition mutually exclusive and antagonistic. The eventual outcome of the divergence between Islam and Communism in Indonesia looked, from Australia, as if it had always existed. Yet in fact, as the comparison with India demonstrates, it had not been inevitable but instead was a recent change brought about by specific political decisions and strategies.

\section{Intersection 2: Trade Unions \& Anti-Colonial Strategies: Tuk Subianto And Eliot V. Elliott}

The sustained friendship between the unionists Tuk Subianto and Eliot V. Elliott offers a example of inter-personal communication across ethnic and national lines through the organisational structure of the international union movement. For a long time, the friendship between Elliott and Tuk Subianto operated in association with the very active international role played by the Indonesian Trade Union movement until 1965, when there was also a robust Indonesian international presence in the women's and youth movements (McGregor 2010). Tuk Subianto was therefore not dependent on Elliott for international access. Instead, the two met on equal terms. This, along with the very public documentation of their work, allows a better understanding of how the common view point they shared in 1945 was sustained and then undermined. ${ }^{10}$

Tuk Subianto had come to Australia in 1943 as a 19 year old Javanese seamen on a merchant ship, trapped outside his country when the Japanese invaded. These Indonesian seamen demanded equal wages with Australian and other Empire seafarers and were immediately jailed alongside the political prisoners brought from Digul prison in West Irian by the Dutch who had hoped they would help to establish a resistance against the Japanese. Eventually released and by then thoroughly politicised, Tukliwan was elected in 1944 to be General Secretary of SARPELINDO, the new union formed in Australia by Indonesian seamen with the support of the Digulists. Eliot V. Elliott, the Melbourne seaman and communist who had become General Federal Secretary of the Seamen’s Union of Australia (SUA) in 1941 became the SUA representative to SARPELINDO while Barney Smith, the NSW SUA

\footnotetext{
${ }^{10}$ Much of the biographical detail on Eliot V. Elliott comes from Rowan Cahill, 1998: 'Sea Change/ An essay in Maritime Labour History', http://www.takver.com/history/seachang.htm; See also Brian Fitzpatrick and Rowan Cahill 1981: The Seamen's Union of Australia,
} 
Secretary was closely involved with both the Indian seafarers and the Indonesians (Healy 2007).

Returning to Indonesia in 1946, Tuk Subianto became General Secretary of the Indonesian Seamen's and Dockers' union, SBPP, in February 1953 (Elliott 1997, pp. 112-116). In this role, he published an article in the Indonesian workers' newspaper Bendera Buruh in October 1953, outlining his key principles for an Indonesian audience. He argued that the waterfront and the maritime industries remained under the control of foreign monopolist capital and that, with support from regulations enacted by the new Republican government, profits still flowed to KPM and other Dutch shipping lines. He was in favour of strikes against these industrial conditions but he also explained the necessity to support strikes called for cultural rights such as that the union had fought to ensure the rights to wear Muslim headdress and to be paid an end of Ramadan allowance. His central point was that the situation was directly analogous to colonial conditions in which the old discriminatory racial wages system between Indonesians \& Dutch employees was sustained. He argued that 'in general, the dock and shipping bosses still consider the Indonesian people to be their colonised People' and 'the Fate of the workers is no better than in the Dutch colonial period.' (Bendera Buruh October 1953, translated by Suzan Piper, 2009).

The solutions he put forward were in general to establish international solidarity through the World Federation of Trade Unions (WFTU), a Trade Union network based in Europe although with an extensive network in the non-western world. His primary solution, however, lay in building direct collaborative political and industrial relations with workers in the colonised and newly decolonised world.

Eliot V. Elliott maintained his Indonesian relationships after the repatriation of his seafarer comrades. He stayed in touch with Tuk Subianto and spent 16 days in Indonesia in October 1952, stopping over on his trips overseas, like that in February 1953 when he was headed to the WFTU conference in Prague. His hopes for a transnational future which he saw as a particular strength of his own union, seafaring, continued to be held passionately, as he showed in this late 1953 statement: 
'We transport workers alone, among all the workers in the world, cross the frontiers of the nations on land, cross the oceans in the ships to many different nations and fly through the air to every nation in the world. We are truly international. (Elliott nd), ${ }^{11}$

As a member of the WFTU Transport Division, containing not only seamen but railway aircraft workers, he included them in his speeches but his focus was always on the maritime industry.

He was also devoted to maintaining an international communist network, and although not uncritical of Stalin, he put up a steely defence against the conservative Australian government's attempts all through the 1950s to have the SUA disaffiliate from the WFTU. ${ }^{12}$ In all his defences of the International network, he stressed the importance of alliances and collaboration with the maritime unionists of Asia and particularly of Indonesia. ${ }^{13}$

His reports on Indonesia and Australia offer an important comparison with those of Tuk Subianto. Elliott argued there were historic links and much common ground between the maritime unions in both countries. In his view, the important common goals were the struggle for decent wages and conditions and the commitment to a strong independent national identity. Elliott placed great importance on unionising the thousands of workers in the Asian region and stressed the tenacity of the Indonesian workers and their successes so far. In line with this approach, the Seaman’s Journal from 1953 to 1958 consistently stressed comradeship with Indonesian, Chinese, Vietnamese, Indian and other Asian seafarers. Elliott argued that - for Indonesia just as much as for Australia - it was essentially class analysis which would offer solutions and so alliances between fellow working class unions, through the WFTU, was the way to gain external support.

There were two key differences between Tuk Subianto's and Elliott's positions at this time. The first was that Elliott failed to notice the Indonesian union's interest in campaigns to achieve cultural goals like recognition of Eid at the end of Ramadan as an important holiday.

\footnotetext{
${ }^{11}$ Eliot V. Elliott, probably delivered to the Third, World Trade Unions Congress, Transport Unions, WFTU, Vienna, October 1953. In bundle of correspondence from this Congress in mid 1954 file, Noel Butlin Archives of Business and Labour, Location: E183/21/8.

12 See his published articles in 1953 and 54 for his criticism of Stalin, SUA archives, Noel Butlin Archives of Business and Labour, Location: E183/21/8.

${ }^{13}$ Eliot V. Ellliott, 1953: 'Our Indonesian Neighbour', Communist Review, Feb 1953, pp 37-42; 20 Jan 1953, J.Woddis, WFTU Publications to E.V.Elliott, re delays in publication of article relating to Australia, to which Elliott responded with minor revisions; 12 Mar 1954, E.V.Elliott to F. Leriche, WFTU, Vienna, Austria; both held in SUA archives, Noel Butlin Archives of Business and Labour, Location: E183/21/8.
} 
The second was that Elliott failed to discuss the building of links between decolonising nations. For him, the priority was to support the centralised international organisation, whereas for Tuk Subianto, the priority was seeking out and consolidating bonds between decolonising and newly independent workers, with the WFTU as a secondary - although highly important - set of alliances. Although these were, even in 1953, important differences, they were outweighed by the extensive common ground between the two men and their two union's positions. They spent the next several years in close communication and international collaboration.

The structure through which this could occur was the WFTU, originally established in the UK as a global network between unions, it had become more Soviet-aligned when it was opposed by a newly formed body, the anti-communist ITF, which concentrated its attention on the emerging Cold War in Europe. The WFTU had developed a strong set of partnerships with the Trade Unions of the non-western and newly independent nations. Although based in Eastern Europe, and meeting in Prague and Vienna, the WFTU nevertheless sustained a flow of news from many parts of the globe, including Japan, India, Ceylon and various countries in Africa. However, when the minutes of WFTU meetings are studied, it becomes apparent that the only representatives of these non-western Trade Unions who were consistently present at meetings and were regularly sending updates, reports and proposals, were those from Indonesia. ${ }^{14}$ It was essentially the Indonesians who gave some reality to the important claim of the WFTU to have a non-European membership.

While Elliot was sustaining his communication with the WFTU and with Tuk Subianto, his union came under increasing political and legal attack from the conservative Menzies Government, leading it to reduce its international involvement and focus instead on defending itself against the relentless industrial campaigns of the government. ${ }^{15}$ Nevertheless, Tuk Subianto was invited to the SUA's 1956 conference and given extensive coverage in The Seamen's Journal to discuss the goals of Indonesian maritime unions. The focal point in Tuk Subianto's reports to the Australian conference was that shipping in Indonesia continued to be under foreign control and he stressed that decolonisation was the key to ending the continuing presence of metropolitan capital in the region. He was interested

\footnotetext{
${ }^{14}$ Many WFTU records are held in the archives of the SUA and MUA in the Noel Butlin Archive of Business and Labour, ANU.

${ }^{15}$ Report by J. Tudehope on Asian Maritime Conference, 5-14 October, 1953, SUA archives, Noel Butlin Archives of Business and Labour, Location: E183/21/8.
} 
not just to offer support for others seeking national independence but to benefit from the shared knowledge of common decolonisation struggles. He raised this issue in a number of ways in his main speech to the 1956 Conference, suggesting Australia should participate with Indonesian trade unions in plans for a network of Afro-Asian unions arising from the recent Afro-Asian Conference in Bandung. But in the SUA-written summary of this conference event, this theme was not mentioned at all. ${ }^{16}$

In fact, decolonisation had seldom been addressed in the journal over the previous 12 months. The Bandung conference, held in April 1955, had formed a major turning point in the communication around the globe between colonised peoples (Walker 2005; Mackie 2005, Tan and Acharya 2008, Finane and McDougal 2010; Kahin 1956). The delegates represented two thirds of the world's population. It had drawn representatives from 29 Asian and African newly independent nations, and delegations from those in the midst of anti-colonial wars. The Bandung conference was widely publicised around the world, leading journalist and author Richard Wright to make a great effort to be present so he could write about this historic meeting which he saw as reflecting a world divided by race. Yet the Seamen's Journal did not mention anything at all about the Bandung meeting till April 1956, a whole year after it had happened (Wright 1956; Walker 2005; J.W. Burton 1933, p.4; Dunn 2004; C. Burton 1955; The Seamen’s Journal April 1956, p.9).

There had been other major events for the decolonising world in the period before the SUA conference. In the battle of Dien Bien Phu, the Vietnamese nationalists under Ho Chi Minh had driven the French out of South East Asia, while in Kenya the Mau Mau Uprising had been underway since 1952, striking terror into British colonisers across Africa. Yet there is little reference anywhere in the Seaman's Journal across 1955 or 1956 to those events, or to decolonisation generally in its coverage of the 1956 Annual General Meeting where Tuk Subianto spoke. The Journal frequently featured articles on international peace and disarmament strategies, but these focussed exclusively on European conflicts and there was no mention of decolonisation as a strategic approach to achieving disarmament and peace.

\footnotetext{
${ }^{16}$ The Seamen's Journal: pp 2: 'Facts re Indonesian Seamen', history of 1945 black ban of Dutch shipping; pp 3-5 Report of AGM, largely Eliot V. Elliott delivering report from Committee of Management but also some extracts of Tuk Subianto speech at end p3 and box, p4; Tuk Subianto writes: 'Indonesian Report... National Independence’, p15-17; ‘Australian Seamen Express Appreciation’, p20; Tuk Subianto writes: ‘Impressions of Australia’, p23.
} 
Certainly in 1956, Tuk Subianto and Eliot V. Elliott were demonstrating that they were having real conversations. Their speeches and reports show they had much common ground between them, including a commitment to understanding social conflict as class struggle, although while this was important for Tuk Subianto, it was the dominant theme for Elliott. Each felt that seamen were both in need of international solidarity but were also uniquely able to contribute to building a new, internationalised world. And each advocated the achievement of strong national independence and identity as a goal for all countries.

Yet there were also indications of dissonance in 1956. As Tuk Subianto appeared to be uneasily aware, Australians had failed to recognise the primacy of continued struggle against colonialism for Indonesian activists. The events around Bandung and other key markers of decolonisation had passed unnoticed in Australia, even for an internationally oriented union like the SUA. In a worrying outcome of this disinterest, Australian seamen failed to pursue either the trade union conference which may have resulted from Bandung or indeed any other trade union networks in the decolonising world.

By 1958, the gap between these two old comrades had widened. Tuk Subianto was again invited to be a key SUA guest at the Annual General Meeting in June but this time, his speech is very different. He stressed - politely but sternly - the disappointment he and his union felt about Australian government intransigence on West Irian, the one remaining Dutch colony. Nationalist unions like the Seamen and Dockers Union (SPBB) had bitterly opposed the continuing colonial control of the Dutch over the shipping industry. They did not interpret the Indonesian government's plan to incorporate West Irian as expansionism but rather saw it as the final removal of the colonial power from what had been the Dutch East Indies. The Australian government had refused to approve of the transfer of power from the Dutch to the Republic of Indonesia, not because it was at all interested in the wishes of Melanesian West Papuans, but instead because it feared the expansion of a left-leaning, anti-colonial neighbour to a shared border with its mandated territory in Papua New Guinea. Australia preferred to see the Dutch remain in control (Seamen’s Journal Sept 1958, pp. 12 -13). This, combined with a number of disputes about the failures of Australian employers to pay adequate wages to Indonesian divers along the north coast, led to a souring of relations between the two countries at national level (Martinez 2010). For Tuk Subianto, this was a clear case of the importance of support for decolonisation and it was a shock to him to realise that the 
Australian maritime unions were unenthusiastic about supporting his union's call for an end to Dutch colonial rule.

Eliot V. Elliott's speeches at the 1958 conference suggest that, rather than opposition to the Indonesian calls, the Maritime Unions like the SUA were simply too focussed on the internal pressure from the Menzies government and anti-communists within the labour movement to involve themselves in international affairs. The unions were, at the same time, facing massive technological changes to the industry. The introduction of cranes and later containers led to dramatic losses in jobs in all the Australian maritime industries which weakened the unions. Combined with the continuing political pressure, this forced the SUA to conserve resources by withdrawing further from its previous international presence. It finally succumbed to the pressure it had faced for over a decade when it disaffiliated from the WFTU (The Seamen's Journal, Sept 1958, pp 42-43). With government support, shipping companies began to employ labourers from neighbouring Asian countries to further challenge the wages and conditions for which the Australian unions had fought. The SUA was actually battling the companies which had made these employment decisions, but the challenge the union faced was whether it could keep its campaign rhetoric focussed on the companies rather than on the exploited employees with whom its members were being forced into competition. Could the SUA sustain the relationships which had been built up over the last two decades with Asian Trades Unions and workers?

By 1963 the answer was sadly clear. The SUA was in full campaign mode against the Australian companies like Ampol which were hiring crews outside Australia on less than Australian award wages. Its headlines and editorials made it quite clear that it was targetting the workers as well as the company as it railed against 'Cheap Labour Asian Crews'. The WFTU was still in close enough contact to send a message of support, but it very carefully demanded support for paying 'Australian wages' to crews employed on these boats. The SUA, however, was arguing not about wages but about race: the union demanded - often under Elliott's own by-line - that Australian companies must employ 'Australian crews' ${ }^{17}$ As containerized cargo-handling escalated, job losses spiralled and the government continued its relentless attack with penal clauses applied to unionists and massive fines to the union.

\footnotetext{
${ }^{17}$ The Seamen's Journal, Jan 1963, p 7 'Cheap labor Asian crews', p. 17, campaign image of the campaign against Ampol running in 1962-63; Feb 1963, pp 1 for SUA call for 'Australian crews' as opposed to WFTU call for 'Australian Wages', in reproduced cable of support, same issue, p. 28.
} 
The SUA succumbed: the old racist approaches to defensive unionism, which had not been visible at all in the Seamen's Journal over the previous decades, again came to dominate the pages of the union's newspaper.

Tuk Subianto did not come to Australia again, and in fact there were no Asian delegations to the SUA Annual General Meeting in the years that followed. The shared hopes of 1945 had been submerged in the grim new worlds of mechanisation and job losses in the 1960s. Worse was to come. The escalating anxieties in Indonesia around the rising popular support for the PKI and its links to the Sukarno government led to the events of 1965, when an alleged abduction of a number of Army generals by left wing groups was used as the pretext for a full-scale Army coup led by General Suharto (Vickers 2005). A massacre of PKI members and supporters began which left perhaps half a million people murdered. One of them was Tuk Subianto.

\section{Intersection 3: Gender Across Racial Lines}

None of the authors who have considered 'south-south' networks around Islam, communism or trade union structures have traced interactions through gendered contacts or through sexual relationships. Religious and political leadership, and mobile populations like seafarers, have been predominantly male, and so their transnational networks are assumed to have existed without any involvement with or between women. Similarly, the tensions of the intimate, domestic or private spheres seem irretrievably localized and vernacular and so are removed from the cosmopolitan and the transnational other than in the most 'everyday' sense.

Gendered relationships have of course been intensely entangled with colonial and anticolonial power at both the personal and the organisational level, so they may have offered or utilised the same type of structures and technologies of continued communication as did Marxist or Trade Union networks (Breckenridge et al. 2002; Stivens 2008).

Australia in the 1940s: recognising the personal and the political If the Indian side of the story about the boycott of Dutch shipping has been obscured, ${ }^{18}$ the presence of women has been completely invisible except for the stellar roles of two extraordinary women, Molly Bondan and Lotte Maramis, whose writing has given us a glimpse of their worlds. Yet these two individuals actually represent two larger groups of women. The first, similarly to Molly Bondan in Sydney and Brisbane, were those who

\footnotetext{
${ }^{18}$ Fitzpatrick and Cahill, 1981, Beasley, 1996, Ivens 1946 - but NOT Lockwood 1982 (who just dismembered it and spread it across the narrative in such a way as to make it hard to find)
} 
became involved with Indonesian and Indian seamen through political activism, which at times shifted into personal and intimate relationships. Those more like Lotte Maramis, in Sydney, became involved initially through personal and emotional relationships, although these may then have led them into political activity. These two groups have seldom been recognised, except in the untiring work of another woman, the linguist and educator Jan Lingard, who in her book Refugees and Rebels also sketches out a third group, the small number of women who came from Boven Digul as wives and daughters of the political activists who had been imprisoned by the Dutch, often for many years, on West Irian and who spent most of their Australian time in Mackay in far north Queensland. I would add a fourth group, of whom we know next to nothing, the sex workers of all of the Australian ports, whose interactions with Indonesian and Indian seafaring men may have been as complex, as moving and as politicised as those described by Henry Trotter in South Africa (Trotter 2001) and Luise White in Kenya (White 1990). While this is an important arena of gendered relationships which must have left many different types of impacts, we have little knowledge about it - yet. Even for the first three groups, this comparative paper can add only marginally to this discussion, but will at least to open up some possibilities. Each of the earlier two intersections has a bearing on how these gendered relationships may have played out.

Two of the women interviewed for this project, Phyllis Johnson and Sylvia Mullins, were members of the Communist Party of Australia (CPA). Molly Bondan was not, but her initial connections to the other Australians who were interested in opening contacts with people from any of the South East Asian countries, were assisted by Clarrie Campbell, her employer, who as mentioned earlier had had a long connection with Indian activists and was himself, although a member of the Labor Party, also a close associate of the CPA (Hardjono and Warner 1995, pp 18-21). ${ }^{19}$ For Communists and non-Communists alike in the 1930s and 40s, the possibility of influencing society seemed very real. By 1944, many Australians had become aware of the decolonisation process, and had turned to look at how they could become more engaged with their closest neighbours as they became independent of empire. The work around the unions being established in Australia by seamen like the Indonesians and the Indians was highly attractive - the social clubs being run were in parallel to those run

\footnotetext{
${ }^{19}$ ASIO tried repeatedly to prove that Clarrie was a card carrying CPA member but never succeeded. There is no doubt however that Clarrie, who was a member of the ALP, had extremely close relationships with the CPA and with Communist Parties elsewhere. Note Clarrie's experience organising an Australia India association to raise funds to assist Indians through the severe Bengal famine of 1943.
} 
for Australian and American servicemen but had the additional interest of opening up a window onto the new worlds of emerging nations.

Sylvia Mullins and Phyllis Johnson each described the excitement they felt on meeting people who were in the midst of such dramatic events as decolonisation. ${ }^{20}$ Phyllis laughed about how she was always asking about political figures and parties, while the Indian sailors in the Social Club were mainly trying to practise their English. Both women shared warm friendships with many of the Indians and Indonesians at the same time as they learned about these neighbouring countries. They remembered other young women who came to the Indian and the Indonesian Social Club functions for similar reasons - combining political interest and developing friendships. Sylvia was one who took an active role, being in the protests beside a Dutch ship strike-bound at Sydney docks, where she was photographed being drenched by the Dutch crew's fire hose. Molly Warner became even more directly involved (Hardjono and Warner 1995, pp 1-41). She moved from helping to set up the new AustraliaIndonesia Society, to developing a personal relationship with Mohammed Bondan, an exDigulist who was active in contacting the new Indonesian government, and then herself taking on a role in operating the radio to receive broadcasts from the Republican government and writing the press releases to circulate the news. She married Bondan and they began a life together which continued when she joined him in Indonesia where she remained for the rest of her life.

The other major group of Australian women, like Lotte Maramis, became involved with Indonesians when the young men exiled in Australia when the Japanese invaded were invited socially to their family homes. All groups of Indonesians, those accidentally caught and those like the ex-Digulists who had been brought by the Dutch, were eventually able to mix relatively freely with Australians in a number of towns and cities all along the eastern seabord, which opened up social and cultural interactions which had not been known in Australia for many decades, if at all. Lotte fell in love with Anton Maramis and married him with her family's support, although she battled much antagonism from the broader Australian public she encountered (Maramis 2006, pp.5-36). Many other young Australian women faced strong opposition from families and friends to the decisions they made to marry their Indonesian fiancés and return with them to their homes once Independence had been

\footnotetext{
${ }^{20}$ Phyllis Johnson (born 1917), interviewed Heather Goodall, Padstow, NSW, 10 May 2007; Sylvia Mullins (born 1925) interviewed Heather Goodall, Normanhurst, NSW, 13 Mar 2007.
} 
declared. As Lingard has documented (2008, pp.237-248), for some of these women the marriages were not successful in such different environments. But for others - and Lotte and Molly were not alone - these relationships proved strong enough to embrace and flourish in the very different society and cultures they found in Indonesia.

These relationships generated ongoing networks in those situations where communication continued. Molly and Lotte, for example, both became journalists who sent news of the newly independent Indonesia out to the broader English speaking world, offering another perspective to add to the stories of the exiting Dutch but also to the emerging voices of Indonesians themselves on the world stage, including women.

The third group of women in Australia were the Indonesian wives and daughters of the political prisoners who had been in Boven Digul and had been brought to Australia by the Dutch. Lingard has written about Siti Chamsinah, the daughter of an ex-Digulist who lived in Mackay, who came to Melbourne to train as a nurse. Even as young woman in the 1940s, Siti made clear her opposition to Dutch rule and, as Lingard discovered when she met her many years later in Indonesia, she had remained a strong-minded and thoughtful woman all her life (Lingard 2008, pp.97-98). We do not know what became of the other Indonesian women who had been associated with Boven Digul and returned to the new Republic - this remains to be followed up in later research. What is clear is that as women's organisations took shape after Independence in Indonesia, they began to look for international networks.

In 1950 Gerwis was been formed from an amalgamation of six small women's organisations across Java. It had an association with the PKI, although not a direct affiliation and it did not always follow PKI advice. It was chastised by the PKI in 1951, for example, for concerning itself with 'political' issues like opposition to the Dutch retention of West Irian, instead of focussing on the local and everyday concerns of non-elite women. Gerwis defied the party by continuing to express this concern and seemed happy to have a distance from the Party. Internationally, Gerwis looked to the WIDF, (the International Federation of Democratic Women) which had been formed in Paris in 1945. The WIDF became a Soviet-aligned body in the turmoil as the Cold War took shape, in a way not dissimilar to that of the World Federation of Trades Unions (WFTU) which had begun as a British-based global body but, after being abandoned by the anti-communist unions, had ended up aligned to the Soviets (Lewis 2003). In Australia, the body aligned with the WIDF was the Union of Australian 
Women (UAW) a left leaning organisation which included members of the CPA but was also joined by women of a wide range of other affiliations (Curthoys and McDonald 1966). One of the key members of the UAW was Jessie Street, who had been also a founding member of the Australian Indonesian Association (Hardjono and Warner 1995, p.19).

The link was made between Gerwis and the UAW at least as early as March 1954, when the Australian women's organisation was formally invited to attend the second congress of the Indonesian women’s movement (Curthoys and McDonald 1966, pp. 36-7; Hindley 1964, pp. 203-5). The WIDF sent delegates as well and at this meeting, the Indonesian organisation changed its name to Gerwani to reflect its decision to address the interests of women of all classes, religions and ethnic affiliations. This was a significant step - as Tan Malaka had pointed out, relations between the left and Islamic groups in Indonesia were fragile even in 1922 and they had worsened in the 1940s. Gerwis - and later Gerwani - were opposed to some practices of Islam in Indonesia, such as polygamy, although not to Islam itself Wieringa 1993; Wieringa 2002; McGregor and Hearmann 2007). The change of name reflected the diverse interests of its expanding membership, encompassing women and children's health, education and rights in families and marriage as well as world peace and disarmament (Hindley 1964; Wieringa 1993, 2002). These were consistent with the goals of the WIDF which stressed education and maternal and child health in all their campaigns.

This diversity of interests and affiliations was a hallmark of the UAW as well, despite its orientation to the left. Whether there was any personal link between Gerwis and the UAW, such as a connection through Jessie Street, is not clear - indeed it is not yet known whether Gerwis contained any of the ex-Digul women who had been in Australia from 1943 to 1945. The link may rather have been only through the formal structures of the WIDF. In any event, UAW members attended the conference in Indonesia which led to sustained communication such as inviting a formal delegation from Gerwani to Australia in March 1960 to mark International Women's Day (Our Women 1960).

Recent research by Kate McGregor shows that through the 1950s, Gerwani was taking a similarly activist role on the world stage in the WIDF as Tuk Subianto, on behalf of the Indonesian Dockers and Seamen's union (SBPP), was taking at the WFTU. Just like the WFTU, the WIDF identified itself as the body which had reached out to the decolonising and non-European world. Yet also like the WFTU, although there were many countries in Africa, Asia and South America on the WIDF membership lists, it was most often the Indonesian 
delegations from Gerwani which actually attended the conferences around Europe and it was the Gerwani leaders like Mrs Mudigno, Sudjinah and Sulami who wrote to the WIDF Executive with ideas, proposals, reports and motions. The Gerwani interventions were aimed at moving the WIDF concerns away, for example, from those of European social structures to look at the needs of women in decolonising countries, such as Indonesian peasant women. Consistently Gerwani pressed for WIDF support for decolonisation struggles and it was Gerwani delegates who pointed out the importance of the 1953 Colombo Conference and the 1955 Bandung Afro-Asian Conference to the WIDF executive office in East Berlin (McGregor 2010).

The Bandung Afro-Asian conference was of high importance in Indonesia, not only for unionists like Tuk Subianto but across the whole population. It had demonstrated the effectiveness of Indonesia's voice on the world stage as well as opening up the very exciting possibilities of practical cooperation between newly decolonised nations. Although the conservative Australian government rejected approaches to attend, Australian voices were strongly evident. Not only were there two Australian 'observers', but the English language accounts of the conference beamed overseas included the work of two of the Australian women, Lotte Maramis and Molly Bondan, working as journalists in their new home (Hardjono and Warner, 1995, pp 102-105; Maramis: 2005, pp 183-199). They wrote in very different styles from each other, reflecting their differing political orientations, but each reflected an enthusiasm for the decolonising world which had been so evident in the Australia of the 1940s, on all sides of politics, but which had retreated there by this time under the Menzies regime.

Gerwani brought its concerns to Australia. Representatives of Gerwani expressed their goals to the UAW for recognition of women in non-industrial economies and support for the decolonising world during visits in the 1950s and again in 1960. Particularly important was Roesijati Sukardi, a journalist who led a Gerwani delegation in 1960 and in the trips the UAW members made to Indonesia in 1962 and again in 1964. The General Secretary of Gerwani, Mrs Kartinah wrote to the UAW after Roesijati Sukardi's visit, returning to the theme of West Irian. She suggested that the Australian organisation might join Gerwani in its opposition to the Dutch decision to send troops to West Irian (Our Women 1960, p 3). Unlike the Seamen's Union in 1958, the UAW was listening to the Indonesian argument and agreed with it, beginning from that time to voice its concerns about the West Irian question. The 
UAW may have been more responsive because it was not facing the overwhelming challenges being confronted by the SUA. Nevertheless, the UAW was one of the very few Australian organisations which from 1960 supported the Indonesian claims to West Irian.

Events in Indonesia overtook Gerwani. The massacre of PKI members and anyone associated with the PKI which began in 1965 took a particularly devastating form for Gerwani members. The organisation as a whole was said to have been complicit in the initial, alleged coup in which six army generals were abducted and murdered. Gerwani members were accused of enacting obscene tortures and of castrating each of the men. Not only was this accusation never substantiated, or even pursued in later trials when the women were charged with different offences, but the autopsies on the generals demonstrated there had not been any castration (Wieringa 2002). Yet the accusations were widely believed. ${ }^{21}$

The imprisoned Gerwani women, after suffering torture and rape, were eventually released, often a decade or more after 1965. But they found that the pornographic defamation of themselves and their organisation was being perpetuated. Even after the fall of Suharto, when there was a tentative rehabilitation of others who had suffered long jail sentences, the denigration of Gerwani continued. The rising influence of Islam on Indonesian society has been suggested as the reason that Gerwani members continue to be distrusted, even by young members of the women's movement (Allard 2009). It has taken huge acts of courage for Sudjinah and Sulami to publish their memoirs, but even these accounts of torture and false imprisonment have not yet been effective in challenging that distrust. ${ }^{22}$

The two notable Australian women who had been in Indonesia were not directly caught up in the 1965 events and neither wrote about it as journalists. Lotte Maramis and her husband were nationalists who had always been opposed to Communism, and they had in any event

\footnotetext{
${ }^{21}$ Indonesia: The Prison State, 1975, Tapol (Political Prisoner) Number 1, 1975, Newsletter of the British Campaign for the Release of Indonesian Political Prisoners; Anne Pohlman (2004) 'A fragment of a story: Gerwani and Tapol experiences', Intersections, Issue 10, August, http://wwwsshe.murdoch.edu.au/intersections/issue10/pohlman.html, see image, (p12 Pohlman): 'Women on Trial, Jakarta’, February 1975, Left to right: Suharti Harsono, Sri Ambar Rukmiati, Sudjinah \& Sulami.'; Katherine McGregor \& Vannessa Hearman, 2007: 'Challenges of Political Rehabilitation in post-New Order Indonesia” the case of Gerwani (the Indonesian Women's Movement) in South East Asia Research, 15(3) pp 355-384; Anne Pohlman, 2009, 'Vivisection and verification: Appadurai's uncertainty and mutilation during the 1965-66 massacres in Indonesia', Conference paper, Session 7, Killings of 1965, Indonesia Council Conference, 17 July, 2009, University of Sydney.

${ }^{22}$ McGregor and Hearman, 2007, have analysed the memoirs of Sudjinah and Sulami and interviewed other Gerwani survivors. See Wieringa, 2002, Pohlman 2004, and McGregor and Hearman 2007 for discussion of continuing attitudes to Gerwani.
} 
returned to Australia before the massacres. Molly and her husband were associated with the left but Mohamad Bondan had refused all party political positions in Indonesia since his return in the 1940s, so they were not targets themselves. Bondan was given a role in the new public service but, after a polite interval, retired and was soon joined by Molly (Bondan 1992, p. 285). With a son and stepchildren there, Molly must have felt that they were all vulnerable. She undertook low-key roles, editing and translating independently and assisting Bondan with his writing, including translating his digest of Indonesian newspapers which they hoped would give English-speaking observers a better sense of how Indonesian society and its commentators were writing (Bondan 1992, p.285; Hardjono and Warner, p. 145). Her only comments about 1965 were oblique, published in the early 1990s and in English, in her book about Bondan's life, Spanning a Revolution, and in her own writings In Love with a Nation. ${ }^{23}$ Neither of these books was translated into Indonesian till 2008. Molly did not mention the women's movement, but she is quoted in In Love with a Nation as believing it had been a grave error for the Communist Party to have become so alienated from the Islamic religion in Indonesia, a point with which Tan Malaka would have strongly agreed. She went on sadly:

'You don't have to believe in karma to see what the social consequences of that awful millstone of murders and injustices around our necks could be. Well, we'll just have to work through our national karma!'(Hardjono and Warner 1995, p.142).

The writing that Lotte Maramis and Molly Bondan did publish has given Australians and other English-speaking readers many glimpses they would not otherwise have had of life in Indonesia. They could not overcome, however, the chasm that opened up after the violence of 1965 had severed the most active ongoing connections which Australian women had with Indonesian women. The UAW reported sadly in Our Women that Gerwani had been closed down and this put an end to the mutual visits between the UAW and women's movement in Indonesia (Our Women, vol.29, p.12).

\section{Conclusion}

Returning to compare these ‘southern' cosmopolitanisms as they frayed apart, there may only be tentative conclusions to draw.

\footnotetext{
${ }^{23}$ Spanning a Revolution was finished by Molly in 1989 but still in press when she died in 1990. The collections of her writings by Hardjono and Warner were published 1995.
} 
There are certainly many more questions than conclusions. One question is what became of the Indians who were so active in building relationships along the networks both of Islam and of shared labour experiences in the 1940s. There seems to have been little Indian presence in those 1950s meetings of the WFTU in Europe where both the Australians and the Indonesians participated. There was certainly correspondence from Ceylon and from a number of smaller, separated areas in India, and it is unlikely that the militant, left-leaning maritime unions in South Asia would have been involved with the anti-communist ITF. But there appears to have been little contact in the diverse but Soviet-aligned networks, like the WFTU and the WIDF, with the major Indian seafaring unions which had been so visible in the global scene in the 1940s. Nor were there any delegates from newly emerging Pakistan, from where so many of the seafarers before 1947 had come and to which they expected to return.

Another question is whether and how the long-established networks of Islam - which had operated to enable some interactions between the mobile Indian and Indonesian seafaring groups in 1945 - might have sustained such connections in the decades afterwards. The sources used for this investigation, such as communist and trade union archives and oral histories arising from Australians, the group least likely to have been aware of the Islamic networks, cannot be expected to be offer much useful evidence to answer this question. But it is notable that just posing the comparison with the Indian situation demonstrates that the rupture in connections between Islam and the political left which occurred in Indonesia was not inevitable, no matter how unproblematic it appeared to be to Australians. The Indian comparison must return our focus to the need for research into the specific conditions which opened up and then perpetuated that breech in Indonesia because it did not occur in India.

In the interactions we can trace - largely those between Australians and Indonesians - there seem to have been a useful roles played by the universalist European-origin structures which had been generated by international communism, international trade union networks and the international women's movement. Of the two latter structures - the left wing organisations the WFTU and the WIDF - there appears to have been far greater diversity in the International Women's movement and as well to be more flexibility in responding to the perspectives of those from outside any one country. This may reflect the levels of relative power represented by the two groups - the Trades Unions for example were clearly often bearing the brunt of the policies of national governments, whereas in Australia at least, the 
women's movement was not in this position. Being marginal to the main power struggles of the day allowed the women's organisations to respond more rapidly and more innovatively to the perspectives of those international or cross-cultural groups with whom they might be in close touch.

Yet in the cases where the European structures did offer a useful platform for meeting and communicating, it was always the case that decolonising country delegates like those from Indonesia felt the need to challenge these bodies. It was only pressure from the Indonesian and delegates from other decolonising nations in both organisations which led them to open up some of their policies and programs to revision. The demands to pay more attention to the needs of non-western and non-urban workers were examples of the ways in which people like Tuk Subianto and the Gerwani delegates could reshape those European-origin networks so they became much more genuinely a place of refuge and support for campaigning 'southern' working people.

At a personal level, the meetings and conferences of those international structures offered opportunities for people like Tuk Subianto and Eliot V. Elliott to stay in touch and to talk over their common ground. The events in each home country - shaped and responding to both external 'Cold War’ pressures but also local dynamics and demands - eventually widened the gap between old comrades. Ultimately, rapidly changing economic conditions and then the catastrophic violence of warfare and massacre had severed the last links.

However, it is clear that some of these personal bonds in 1945 had proved to be able to withstand the early shocks of independence, partition and electoral defeats. At least for a decade, those bonds - and indeed just the hopes of ongoing communications - had been resilient enough to keep people looking for ways to collaborate. Those 'new worlds' may not have turned out to be what people had hoped for in 1945, but perhaps the attempts made to keep searching for them have left some legacies.

\section{Acknowledgments}

A number of people have contributed to this paper. I would like to thank Suzan Piper for painstaking translations and thoughtful contributions to research strategies. Kate McGregor and Julia Martinez have been generous in their advice and suggestions for sources. At heart, a central contribution has been made by those people who remembered the struggles to cross 
borders and keep in touch during the 1940s and 50s: Phyllis Johnson, Sylvia Mullins, Jack Mullins, Lotte Maramis and Audrey McDonald.

\section{References}

Allard, T. 'Indonesia unwilling to tackle legacy of massacres', 13 June 2009, Sydney Morning Herald.

Anderson, B. 1976 and 2006, 1953: Java in a Time of Revolution: Occupation and Resistance, 1944-1946, Equinox, Djakarta.

Anderson, B. 1979, 'A Time of Darkness and a Time of Light: transposition in early Indonesian nationalist thought' in Reid, A. and Marr, D. (eds) Perceptions of the Past in Southeast Asia, ASAA Southeast Asia Publications Series, Heinemann Educational books, Singapore, pp.219- 248.

Beasley, M. 1996, Wharfies: A history of the Waterside Workers' Federation of Australia, Halstead Press, Sydney.

Bondan, M. 1992, Spanning a Revolution: Mohamad Bondan and the Indonesian Nationalist Movement, Pustaka Sinar Harapan, Jakarta.

Bose, S. 2010, 'Different universalisms, colorful cosmopolitanisms: the global imagination of the colonised', in Bose, S. and Manjapra, K. (eds) Cosmopolitan Thought Zones: South Asia and the Global Circulation of Ideas, Palgrave Macmillan, Houndmills, UK, pp. 97-111.

Sugata Bose and Kris Manjapra (eds) Cosmopolitan Thought Zones: South Asia and the Global Circulation of Ideas, Palgrave Macmillan, Houndmills, UK.

Breckenridge, C., Pollock, S., Baba, H. and Chakrabarty, D. (eds) 2002, Cosmopolitanism, Duke University Press, Durham.

Broeze, F. 1981, 'The muscles of empire - indian seamen and the raj 1919 - 1939', Indian Economic and Social History Review, vol.1, pp. 43-67.

Broeze, F. 1998, Island Nation: A History of Australians and the Sea, Allen and Unwin, Sydney.

Burchett, W. 1955, 'Bandoeng was a great victory for world peace', The Guardian, 5 May.

Burton, J.W. '1933, Report on the Bandung Conference', (8 pages) p4, National Archives Australia (NAA) A 6122; 1933, NAA.

Burton, C. 1955, 'Report on Bandung’, Meanjin, Sept 1955, pp 395-399.

Bendera Buruh, October 1953, translated by Suzan Piper, 2009.

Chattopadhyay, S. 2011, An Early Communist: Muzaffar Ahmad in Calcutta 1913 - 1929, Tulika Books, New Delhi.

Cottle, D. 2003, 'Forgotten foreign militants: the Chinese Seamen's Union in Australia, 19421946’, in Alexander, H and Griffiths, P. (eds) Rough Reds: Australian Stories of Rank and File Organising, Canberra, Australian Society for the Study of Labour History, pp. 135-151; http://roughreds.com/rrone/index.html

Cottle, D. and Keys, A. 2006, 'From Colonial Film Commissioner to Political Pariah: Joris Ivens and the Making of Indonesia Calling', http://www.sensesofcinema.com/2006 /41/ivens-indonesia-calling Accessed 28 November 2011.

Curthoys, B. and McDonald, A.1966, More than a Hat and Glove Brigade, Union of Australian Women, Sydney

Delanty, G. 2009, The Cosmopolitan Imagination: The Renewal of Critical Social Theory, Cambridge University Press, Cambridge.

Dunn, D. 2004, From Power Politics to Conflict Resolution: The work of John W. Burton, Palgrave MacMillan, Houndmills, UK. 
Elliott, J. 1997, ‘Bersatoe Kita Berdiri Bertjerai Kita Djatoeh’ [United we stand Divided we fall'] Workers and Unions in Indonesia: Jakarta, 1945-65, unpublished PhD, University of New South Wales.

Ewald, Janet 2000, 'Crossers of the sea: slaves, freedmen, and other migrants in the northwestern Indian Ocean, c. 1750 - 1914', American Historical Review, vol.105, pp.1-42.

Fadilla, A. and Soemadi, A., Indonesian Political Exiles Association, Mackay, Qld, 4 Dec 1945, ISUiA Archive, E177/5. Noel Butlin Archive of Business and Labour, Menzies Library, ANU.

Falkiner, S. 2008, Joan in India, Australian Scholarly Press, Kew, Vic.

Fealy, G. and Katharine McGregor, 2010, 'Nahdlatul Ulama and the killings of 1965-66: Religion, politics and remembrance', Indonesia, vol. 89, April, pp. 37-60.

Federspiel, H.M. 2006, Indonesian Muslim Intellectuals of the $20^{\text {th }}$ Century, ISEAS Publications, Singapore, pp.23-25.

Finane, A. and Derek McDougal (eds), 2010, Bandung 1955: little histories, Monash University Press, Melbourne.

Fitzpatrick, B. and Rohan Cahill, 1981, The Seamen's Union of Australia: 1872-197; A History, The Seamen's Union of Australia, Sydney.

Frost, M.R. forthcoming: Dreams of Other Empires: The cosmopolitan moment in the Indian Ocean world, 1870-1920.

Frost, M.R. 2004, 'Asia's maritime networks and the colonial public sphere, 1840-1920', New Zealand Journal of Asian Studies vol. 6, no.2, pp. 63-94.

Frost, M.R. 2010, 'In search of cosmopolitan discourse: a historical journey across the Indian Ocean from Singapore to South Africa, 1870 - 1920' in Gupta, P., Hofmeyr, I. and Pearson, M. (eds) Eyes Across the Water: Navigating the Indian Ocean, UniSA Press, Pretoria, pp. 75-96.

Germain, E. 2007, 'Southern hemisphere diasporic communities in the building of an international Muslim public opinion at the turn of the twentieth century', Comparative Studies of South Asia, Africa and the Middle East, vol. 27, no. 1, pp. 126-138.

Goodall, H. 2008, 'Port Politics, Race and Change: Indian Seamen, Australian Unions and Indonesian Independence, 1945 -1947’, Labour History, vol. 94, pp. 43-68.

Goodall, H. 2010, 'Shared hopes, new worlds: Indian seamen, Australian unionists \& Indonesian independence 1945 - 1949' in Moorthy, S. and Jamal, A. (eds) Indian Ocean Studies: Cultural, Social, and Political Perspectives, Routledge, London, pp 158-196.

Hardjono, J. and Warner, C. 1995, In Love with a Nation: Molly Bondan and Indonesia, Charles Warner, Picton, Australia.

Healy, C. 2007, 'Recollections of the 'Black Armada' in Brisbane', Vintage Reds: More stories of rank and file organizing, Australian Society for the Study of Labour History, http://roughreds.com/rrtwo/healy.html Accessed on 28 November 2011.

Hindley, D. 1964, The Communist Party of Indonesia 1951-1963, UCLA Press, Berkeley.

History of the WFTU (paper presented WFTU Congress, Delhi, 2000) http://www.hartfordhwp.com/archives/26/041.html

Kahin, G.1956, The Asian-African Conference, Bandung, Indonesia, April, 1955, Cornell University Press, Itaca New York.

Kumar, A. 1979, 'Javanese historiography in and of the 'Colonial Period' in Reid, A. and Marr,D. (eds) Perceptions of the Past in Southeast Asia, ASAA Southeast Asia Publications Series, Heinemann Educational books, Singapore, pp.187-206. 
Lewis, H. 2003, The International Transport Workers' Federation (ITF) 1945-1965: an Organizational and Political Anatomy, unpublished PhD, Sociology, University of Warwick.

Lingard, J. 2008, Refugees and Rebels: Indonesian Exiles in Wartime Australia, Australian Scholarly Publishing, Melbourne.

Lockwood, R. 1982, Black Armada: Australia and the struggle for Indonesian independence 1942-49, Hale and Iremonger, Sydney.

Mackie, J. 2005, Bandung 1955: Non-Alignment and Afro-Asian Solidarity, Editions Didier Millet, Singapore.

Mundell, I. 2005, Joris Ivens, Biography, 2005, Senses of Cinema Online, Database of Great Directors, http://www.sensesofcinema.com/2005/great-directors/ivens Accessed 24 Feb 2008.

Tan Malaka, 1922, Speech to Fourth Congress of Communist International, http://www.marxists.org/archive/malaka/1922-Panislamism.htm

Manjapra, K. 2010a 'Communist internationalism and transcolonial recognition' in Bose, S. and Manjapra, K. (eds) Cosmopolitan Thought Zones: South Asia and the Global Circulation of Ideas, Palgrave Macmillan, Houndmills, UK, pp. 159-177.

Manjapra, K. 2010b, M. N. Roy: Marxism and Colonial Cosmopolitanism, Routledge India, Delhi

Maramis, C. 2006, Echoes Book One: Australia and Indonesia, Best Legenz, Sydney.

Maramis, C: 2005, Echoes: Book Two: My Years in Indonesia, 1949-1962, Self published, Sydney.

Martínez, J. 2001, “’Coolies” to Comrades: Internationalism between Australian and Asian Seamen' in Markey, R. (ed.), Labour and Community: Historical Essays, University of Wollongong Press, Wollongong, pp. 295-312.

Martínez, J. 2010, 'Timorese indentured labour in Australia', Paper presented at Indonesians Overseas conference University of Wollongong, December 2010.

McGregor, K. 2009, 'A Reassessment of the significance of the 1948 Madiun Uprising to the cold war in Indonesia', Kajian Malaysia, Jld. vol. 27, no. 1\& 2, 2009

McGregor, K. 2010, 'Gerwani, the WIDF and Anti-Imperialism: the dynamics of a transnational cold war alliance’ Paper presented at the Indonesians Overseas conference, University of Wollongong, December 2010.

McGregor, K and Hearman, V, '2007, 'Challenges of political rehabilitation in post-new order Indonesia” the case of Gerwani (the Indonesian Women's Movement) South East Asia Research, vol.15, no.3, pp. 355-384.

McVey, R. 1965, The Rise of Indonesian Communism, Cornell University Press, Ithaca.

Our Women: National Magazine of the UAW, Number 17, October-December 1960, pp 2-3.

Raliby O. 1953, Documenta Historica, Bulan-Bintang, Jakarta.

Reetz, D. 2006, Islam in the Public Sphere: Religious Groups in India, 1900-1947. Oxford University Press, New Delhi.

Reid, A. 1979, 'A Nationalist Quest for an Indonesian Past’ in Reid, A. and Marr,D. (eds) Perceptions of the Past in Southeast Asia, ASAA Southeast Asia Publications Series, Heinemann Educational books, Singapore, pp 281-298.

Ricklefs, M.C. 2001, A History of Modern Indonesia since c. 1200, Third Edition, Palgrave, Basingstoke.

Rumford, Chris 2008, Cosmopolitan Spaces: Europe, Globalisation, Theory, Routledge, New York.

The Seamen's Journal 1945 -1965, Noel Butlin Archive of Business and Labour, Menzies Library, Australian National University. 
Shiraishi, T. 1990, An Age in Motion: Popular Radicalism in Java, 1912-1926 (Asia East by South) Cornell University Press, Ithaca.

Stivens, M. 2008, 'Gender, Rights and Cosmopolitanisms', in Werbner, P. (ed.) Anthropology and the New Cosmopolitanism, Berg, Oxford, pp. 87-110.

Tan, S. \& Acharya, A. (eds) 2008, Bandung Revisited: The Legacy of the 1955 Asian-African Conference for International Order, NUS Press, Singapore.

Tribune, Tues 23 October, 1945, p 1, 'Indians Prevent Dutch Getaway'

Tribune, Friday 26 October, 1945, p 3, 'Indians Defy Dutch, Enter Lido.',

Tribune, Tues 30 October, 1945, 'Indians Establish Complete Dutch Ship Boycott'.

Tribune, 2 November, 1945

Tribune, 27 November, 1945, p7

Tribune, 23 November, 1945, p8

Trotter, H. 2011, Sugar Girls and Seamen: A Journey into the World of Dockside Prostitution in South Africa, Ohio Press, Athens.

Valentine, G. 2008, 'Living with difference: Reflections on geographies of encounter', Progress in Human Geography vol. 32, no. 3, pp.323-337.

Vickers, A. 2005, A History of Modern Indonesia, Cambridge University Press, Cambridge.

Walker, David, 2005: 'Nervous outsiders', Australian Historical Studies, 36: 125, 40 - 59;

White, L. 1990, The Comforts of Home: Prostitution in Colonial Nairobi, University of Chicago Press, Chicago.

Wieringa, S. 1993, 'Two Indonesian women's organizations: Gerwani and the PKK', Bulletin of Concerned Asian Scholars, vol.17, no.2, pp 17-30.

Wieringa, S. 2002, Sexual Politics in Indonesia, Palgrave McMillan, New York.

Win, Kyaw Zaw 2011, 'The 1953 Asian Socialist Conference in Rangoon: precursor to the Bandung conference', in Finane, A. and McDougal, D. (eds), Bandung 1955: little histories, Monash University Press, Melbourne, pp 43-56.

Wright, R. 1956, The Color Curtain: A Report on the Bandung Conference, World Publishing Company, Cleveland.

Zurbuchen, M. (ed.) 2005, Beginning to Remember: The Past in the Indonesian Present, Singapore University Press and Washington University Press, Seattle. 